\title{
Using Waste Heat to Dry RDF: a Technical and \\ Environmental Assessment of the Low Temperature Belt Dryer Technology
}

\author{
Sandro Conceição (Corresponding author) \\ InterCement Group Lisbon, Portugal \\ E-mail: SConceicao@cimpor.com
}

João Rolim

InterCement Group Lisbon, Portugal

Received: March 15, 2019 Accepted: March 22, 2019 Published: April 30, 2019

doi:10.5296/emsd.v8i2.14441 URL: https://doi.org/10.5296/emsd.v8i2.14441

\begin{abstract}
In 2015, the Portuguese cement production company Cimpor modified the alternative fuel supply operation of refuse derived fuel (RDF) co-processing in the main burner of one of its cement kilns in Souselas. This modification resulted in the installation of an RDF drying unit with low temperature belt dryer (LTBD) technology that uses cascading energy available in Souselas cement plant. Implementation of the dryer project improves production and efficiency of the industrial process, while also resulting in environmental benefits as it decreases moisture and increases the lower calorific value of RDF, improving its quality. This paper intended to determine these environmental benefits and the added value that the project brings to the industry by presenting an energy balance and environmental assessment. This methodology allowed to compare the use of available heat as an energy source for the dryer instead of fossil fuels, such as natural gas or coal, which concluded that the waste heat available at the cement plant for the dryer would allow the saving of 75 to $84 \mathrm{~kg}$ of $\mathrm{CO}_{2}$-eq per tonne of wet RDF to be dried. Projects such as this one may greatly help address the main barriers of using RDF from municipal solid waste and other waste streams with high moisture content.
\end{abstract}

Keywords: Low temperature belt dryer, Refuse derived fuel, Co-processing in cement industry, Energy balance, Environmental assessment 


\section{Introduction}

The cement sector is an energy and resource intensive industry which results in significant environmental impacts, namely greenhouse gas (GHG) emissions and raw materials' consumption (Usón et al., 2013; Supino et al., 2016; Georgiopoulou \& Lyberatos, 2018). However, this industry also contributes substantially to the national economy and can be an important agent in the circular economy (The European Cement Association, 2015; Supino et $a l ., 2016)$ due to its capacity to close material and energy cycles that would otherwise be wasted. As such, the transition from an economical model that is based on the (over)exploitation of resources to an economic development model based on the circular economy principles, which preserves and recovers the value of materials for longer periods, is crucial to reduce pressure over the natural system. The activity of co-processing, which resorts to the substitution of conventional fuels and raw materials with alternative fuels and raw materials (AFR) in a standard cement production process, can be an important contribution to this paradigm shift in the sector (European Commission, 2017).

Co-processing is a recovery solution for several waste fractions without recycling potential that would otherwise be landfilled (Baidya et al., 2017; Global Cement and Concrete Association, 2018). The cement kilns, with prolonged gas residence time along with high temperatures and a high level of control and automation, offer the ideal conditions for the safe treatment of non-recoverable materials whilst providing energy to the clinker production process (Rahman, 2013). The environmental benefits of the use of alternative fuels in relation to conventional fuels in the cement production process have been identified in several studies (Genon \& Brizio, 2008; Reza et al., 2013; Sarc et al., 2014; Georgiopoulou \& Lyberatos, 2018).

Co-processing distinguishes itself from incineration or waste-to-energy due to the dual recovery process that takes place in the cement kiln. The combustible fraction is used to provide heat to the calcination process, whereas the mineral fraction is incorporated in the clinker, replacing material inputs that would be needed. Therefore, co-processing is simultaneously an energy and material recovery process, standing between waste-to-energy and recycling in the waste hierarchy. This simultaneous contribution is recognised by several organisations, both public and private (European Commission, 2011a; European Commission, 2011b; United Nations Environment Programme, 2011a; United Nations Environment Programme, 2011b; European Commission, 2012; Joint Research Council, 2013; Ökopol $\mathrm{GmbH}, 2004$ ) and has long been argued by the cement sector as one of the most important improvements in the European Union waste legislation.

In Portugal, co-processing of RDF is significantly limited by the high moisture content of domestic RDF derived from municipal solid waste (Berardi et al., 2016; Ecofys, 2017) and high chlorine content. Due to the low landfill taxes currently implemented in Portugal, it is necessary to create new cost-efficient solutions to divert substantial quantities of waste from landfill. To address this issue, Cimpor, one of two cement companies operating in Portugal, with 3 plants, implemented a low temperature belt dryer (LTBD) that reduces the moisture content of waste and provides a better process control, enabling a higher uptake of alternative 


\section{Macrothink}

fuels. The dryer was installed in the alternative fuel feeding process of the clinker production kiln at Cimpor's plant in Souselas, using excess hot air from the cement production process to dry RDF, significantly contributing to increase the process efficiency and the thermal substitution in one of its clinker kilns.

The introduction of this drying technology in industrial processes is commonly applied in sectors such as food, biomass and sludge (Johansen van Delft, 2010; Alamia et al., 2015; Mäkelä et al., 2017); however, the subject of RDF drying is less common in the reviewed literature (Nzioka et al., 2016; Asadi, 2016).

This study aims to assess the dryer's performance at a technical level and to evaluate and quantify the potential environmental benefits of the implementation of an LTBD in Souselas plant that reuses excess hot air from clinker production to dry RDF for co-processing in the main kiln burner.

To assess the impacts of the dryer project in Souselas, a technical assessment was carried out, addressing the technical specifications of the technology. Additionally, the environmental benefits of using available heat in the LTBD instead of other heat sources were calculated, as well as the avoided environmental impacts of resorting to solid hazardous waste mixtures rather than RDF from municipal solid waste.

\section{Technical Assessment of the LTBD}

In this section, a description of the project and the drying operation conditions is presented, including the results of a performance test carried out in 2016.

\subsection{Process Description}

After being delivered to the cement plant, the waste streams are transported from the waste reception area to storage silos through a conveyor. These silos have dosing systems that distribute the waste either to the precalciner, to the kiln burner or to the waste dryer, through a transport system (Figure 1).

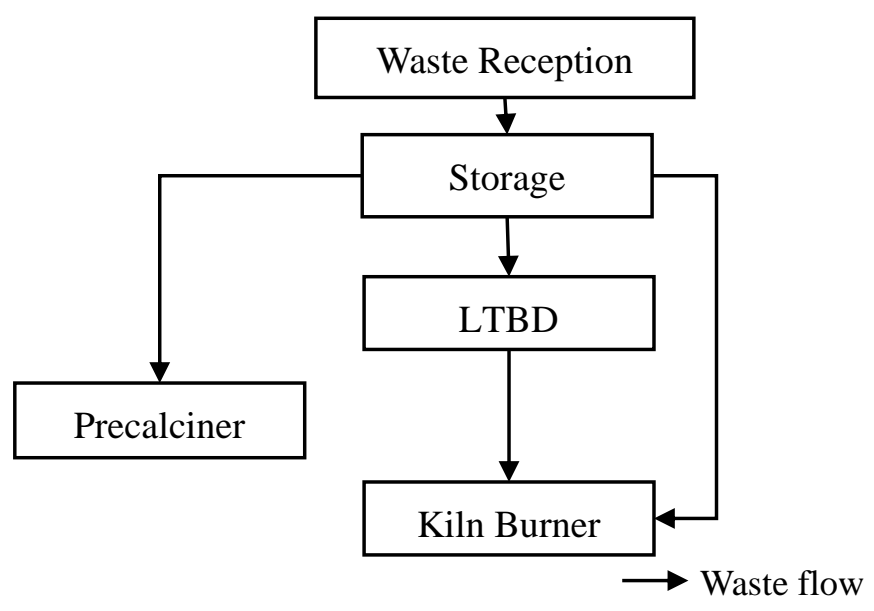

Figure 1. Schematics of the implementation of an LTBD in the cement plant at Souselas 


\section{MInstitute ${ }^{\text {Mach }}$}

The previous transport system to the main burner in Souselas was carried out by pneumatic conveying, but the municipal solid waste (MSW) composition and high moisture content caused several problems that resulted in a low feed of alternative fuels to the kiln. To modify this, Cimpor changed the system to a drag chain conveyor which significantly increased the $\mathrm{RDF}$ feed to the kiln main burner and avoided critical malfunctions that required full stoppages to solve. This upgrade consisted in the readjustment of the existing dosing system, compressor and rotary valve and the installation of two new stainless-steel apron feeders installed with Variable Speed Drive (VSD) and a new bypass valve. In normal operating conditions, this valve is $100 \%$ open to the dryer, diverting some RDF to the bypass according to the intensity of the first screw feeder.

After leaving the dryer, the dried RDF is transported to the main kiln burner through the mechanical conveyor for co-processing. The goal of the project was to increase RDF incorporation in the main kiln burner to 25000 tonnes per year, considering a clinker production capacity of 1156000 t/year.

\subsection{Drying Technology}

The LTBD is based on a thermal drying method that decreases RDF moisture through a continuous process at a low temperature (projected at a maximum of $90^{\circ} \mathrm{C}$ ). The dryer installed in Souselas is an equipment with considerable size (approximately $20 \mathrm{~m}$ x $11 \mathrm{~m}$ x 8 $\mathrm{m})$ and a high level of control that receives the waste from the transport system mentioned in section 2.1., allowing the adjustment of several operational parameters.

The RDF is continuously fed to a polyester conveyor belt which is 12 meters long and 6 meters wide that transports the waste to the drying zone. This conveyor belt is fed by two screw feeders which are parallel to the belt and whose height is adjustable to create a uniform RDF layer along the belt (between $70 \mathrm{~mm}$ and $140 \mathrm{~mm}$ ). Once the RDF is distributed inside the dryer, the excess hot air flows from the clinker cooler reducing the moisture content through convection.

The belt is slightly porous in order to be crossed from top to bottom by a stream of hot air, which comes from the cooler's bag filter fan exit and enters the dryer gas mixing chamber, located in its upper part. If required, fresh air enters the mixing chamber through two flap valves, mixing with hot air to reach an even temperature of 75 to $85^{\circ} \mathrm{C}$ across the top of the belt. The mode of operation of the dryer involves hot air getting sucked from the top downwards through the drying stock convectively. The two flap valves control the belt temperature, reaching the set point established (Stela, 2018).

The passage of hot air through the drying stock results in the removal of water from the RDF. The moist air that comes out of the dryer returns to the cooler stack. The gas circuit consists of a variable speed fan, two isolating air flap valves, at the inlet and outlet of the dryer and one adjustable valve (multilouver) installed in the duct between the bag filter fan and the chimney. To ensure that the dryer does not leak, a rotary valve was installed at the entrance and exit of the dryer. The dried material is discharged by a rotary screw and valve.

RDF moisture is continuously controlled at the exit of the dryer by a micro-wave sensor. This 
sensor is located at the discharge screw and the operation is monitored in the Central Control Room (CCR). Final moisture percentage is adjusted by a Proportional-Integral-Derivative (PID) controller which controls the dryer fan speed, according to a predefined set point. There are four more PID controllers that allow the dryer function to work in automatic mode and that regulate:

- The layer of RDF on the belt, by regulating the speed of the conveyor belt in order to keep it constant;

- The dryer temperature, by regulating the opening/closure of both flap valves;

- The constant RDF feed to the dryer, by opening the bypass valve as a function of the intensity of the screw feeder.

- The bypass opening as a function of the intensity of the screw feeder of the silo outlet allowing a constant RDF level into the dryer.

- The equipment was dimensioned for RDF with a maximum feed rate of 10 tph, with a maximum $40 \%$ of moisture, and an output of $7 \mathrm{tph}$, with $15 \%$ moisture. Technical specifications of this technology are summarised in Table 1.

Table 1. Technical Specifications of the waste dryer installed in Souselas cement plant

\begin{tabular}{|l|l|}
\hline Supplier & Stela Lax Huber (Germany) \\
\hline Dryer type & BT 1/6200-12 \\
\hline Product & $\begin{array}{l}\text { RDF from municipal solid waste without foreign } \\
\text { bodies (loose, not frozen, dust-free, } 10^{\circ} \mathrm{C} \text { ) }\end{array}$ \\
\hline Bulk weight & ca. $100-250 \mathrm{~kg} / \mathrm{m}^{3}$ (wet) \\
\hline Average retention time for drying & 6 to 30 minutes in active zone \\
\hline Bed depth & $70-140 \mathrm{~mm}$ (commissioning adjusted to $130 \mathrm{~mm}$ ) \\
\hline Drying temperature & $\pm 90^{\circ} \mathrm{C}$ \\
\hline Dryer input capacity & $10.0 \mathrm{tph}$ \\
\hline Dryer output capacity & $7.0 \mathrm{tph}$ \\
\hline Input waste moisture content & $40 \%$ \\
\hline Output waste moisture content & $\pm 15 \%$ \\
\hline Water evaporation & $3.0 \mathrm{tph}$ \\
\hline Drying zone & $72 \mathrm{~m}^{2}$ (active drying zone with stream of hot air) \\
\hline Fresh air & temperature of $40^{\circ} \mathrm{C} ; 30-70 \%$ moisture, no dust \\
\hline Dust emission & $<20 \mathrm{mg} / \mathrm{Nm}^{3}$ \\
\hline
\end{tabular}

\subsection{Waste Streams}

The waste stream that has been subjected to the drying process in the start-up phase of the project was solid hazardous waste mixtures. According to the European List of Waste (LoW) (European Commission, 2000), This waste stream is classified as other wastes (including mixtures of materials) from mechanical treatment of waste containing dangerous substances with a LoW code of $191211 *$.

The implementation of the dryer at Souselas cement plant allowed the use of this waste as a fuel, providing a recovery solution to a waste which previously had the landfill as its only destination. The average characterisation of the solid hazardous waste mixtures received between January $6^{\text {th }}$ and October $31^{\text {st }}$ of 2017 from different waste operators is depicted in 


\section{Macrothink}

Table 2.

Table 2. Average characterisation of solid hazardous waste mixtures received in Souselas between 06/01/2017 and 31/10/2017

\begin{tabular}{|c|c|c|c|c|}
\hline $\begin{array}{c}\text { Moisture content } \\
(\% \mathrm{~m} / \mathrm{m})\end{array}$ & $\begin{array}{c}\mathrm{LHV}_{\text {(dry basis) }} \\
(\mathrm{MJ} / \mathrm{kg})\end{array}$ & \begin{tabular}{c}
$\mathrm{LHV}_{\text {(as received) }}(\mathrm{MJ} / \mathrm{kg})$ \\
\hline 36.4
\end{tabular} & $\begin{array}{c}\text { Chlorine content } \\
(\% \mathrm{~m} / \mathrm{m})\end{array}$ & $\begin{array}{c}\text { Ash content } \\
(\% \mathrm{~m} / \mathrm{m})\end{array}$ \\
\hline & 23.3 & 14.0 & 0.9 & 17.6 \\
\hline
\end{tabular}

\subsection{Operation Conditions}

In the beginning of November 2016, a hot commissioning ${ }^{1}$ process was performed. The process started up with the following operating conditions whose resulting variation in RDF moisture is presented in Table 3:

- Air flow at dryer inlet $=119400 \mathrm{Nm}^{3} / \mathrm{h}$ (which corresponds to $75 \%$ of maximum gas flow $-159000 \mathrm{Nm}^{3} / \mathrm{h}$ );

- Air temperature at dryer inlet $=80-84^{\circ} \mathrm{C}$ (in this situation, $<85^{\circ} \mathrm{C}$, cold air dampers do not open);

- The dryer fan was fixed at $90 \%$ speed;

- The multi-louver damper opened at $15 \%$.

Table 3. RDF moisture variation in dryer hot commissioning

\begin{tabular}{|c|c|c|}
\hline RDF supplier & RDF Inlet Moisture (\%) & RDF Outlet Moisture (\%) \\
\hline 1 & 19.0 & 1.7 \\
\hline 2 & 34.3 & 5.0 \\
\hline
\end{tabular}

A 24-hour performance test was carried out in which RDF samples were collected every two hours at the dryer inlet and at the outlet (Figure 2). The average air temperature at the inlet was $76.5^{\circ} \mathrm{C}$ and the dryer fan was set at a speed average of $98 \%$.
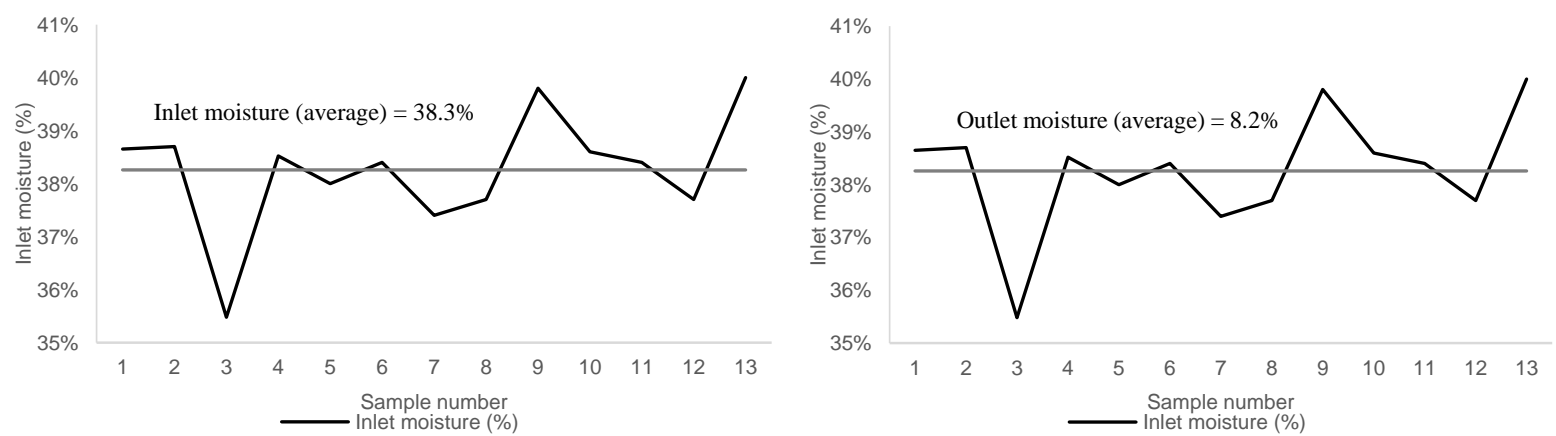

Figure 2. RDF inlet and outlet moisture variation in dryer performance test (every two

\footnotetext{
${ }^{1}$ According to ISPE (2001) Pharmaceutical Engineering Guides for New and Renovated Facilities. Volume 5: Commissioning \& Qualification, commissioning can be defined as a "well-planned, documented, and managed engineering approach to the start-up and turnover of facilities, systems, and equipment to the end user that results in a safe and functional environment that meets established design requirements and stakeholder expectations". Hot commissioning means the design process fluids are introduced in the systems and sub-systems and operating scenarios are developed.
} 
hours sampling)

In this performance test, the RDF's wet feed rate was 7.5 tph instead of 10 tph, due to kiln input chlorine limitation, with a total water evaporation of $2.5 \mathrm{tph}$, which resulted in an outlet moisture content of $8 \%$. This value is actually lower than the moisture content obtained in real operational conditions, where it ranges normally between 10 to $15 \%$. The test proved the dryer operation to be quite stable, as seen in the results depicted in Figure 2.

\section{Environmental Assessment}

Thermal drying can use the heat resulting from a fuel combustion process, such as coal and natural gas. The implementation of an LTBD technology in Souselas that uses available heat from the excess hot air generated in the clinker kiln to dry the RDF avoids the combustion of those resources resulting in environmental benefits.

In this section, an environmental assessment of the project based on Life Cycle Assessment (LCA)-based environmental indicators is developed in order to quantify and evaluate the environmental benefits associated with the project, when compared to the same thermal drying technology without an available heat source from an existing process. This analysis is an iterative process, where acquired experience at the end can contribute to improve the initial stages.

\subsection{Goal and Scope Definition}

The objective of this assessment was to quantify the benefits that result from the implementation of the LTBD technology in the cement plant at Souselas by using available waste heat from the clinker production instead of other heat sources, such as natural gas.

In order to assess this facility's environmental impacts, a comparison was carried out between different heat sources to the implemented technology. The functional unit of this assessment is the amount of energy to dry one tonne of wet RDF.

The environmental assessment is applied to the LTBD technology implemented in the cement plant in Souselas, in which the dryer operation is modelled with foreground data, i.e., data obtained from the dryer's performance test.

By resorting to the waste heat from the clinker production as a heat source, the drying technology manages to avoid the combustion of natural gas in the dryer with hot water as a heat source. Therefore, the only impacts associated with the technology are related to the operation of the dryer itself.

Background data from the database Ecoinvent 3 (Wernet et al., 2016) was used to model the upward processes, namely the extraction and transport of natural gas. Initially, the analysis considered the life cycle impacts of the system equipment, namely the natural gas boiler and the LTBD, but since their results in all impact categories were below the established cut-off, they were excluded from the analysis. 


\section{Macrothink

\subsection{Assumptions and Energy Analysis}

An energy analysis was carried out in order to quantify the amount of energy necessary to dry one tonne of wet RDF according to the equipment's real data obtained in a performance test in Souselas. This allowed to compare the drying technologies with different heat sources and to quantify the benefits of resorting to waste heat from the clinker production process.

Recovery of waste heat to feed the dryer is an efficient way to reduce costs and fuel consumption. Several studies have resorted to energetic and exergetic analyses to assess the viability of waste heat recovery in cement plants for different purposes with positive results (Khurana et al., 2002; Wang et al., 2009; Karellas et al., 2013; Rad \& Mohammadi, 2018).

As depicted in Figure 3, a flow of RDF, with $\dot{m}_{i n}^{R D F}=7.5 t / h$, is fed into to dryer with a moisture content of $w_{i n}=38.3 \%$. A flow of hot air, $\dot{m}_{i n}^{\text {air }}=119400 \mathrm{Nm}^{3} / \mathrm{h}$, enters the dryer at a temperature $T_{i n}=76.5^{\circ} \mathrm{C}$ to reduce the moisture content of the RDF through convection, which then exits at a temperature $T_{\text {out }}=29.1^{\circ} \mathrm{C}$. After the process, the RDF leaves the dryer with $w_{\text {out }}=8.2 \%$.

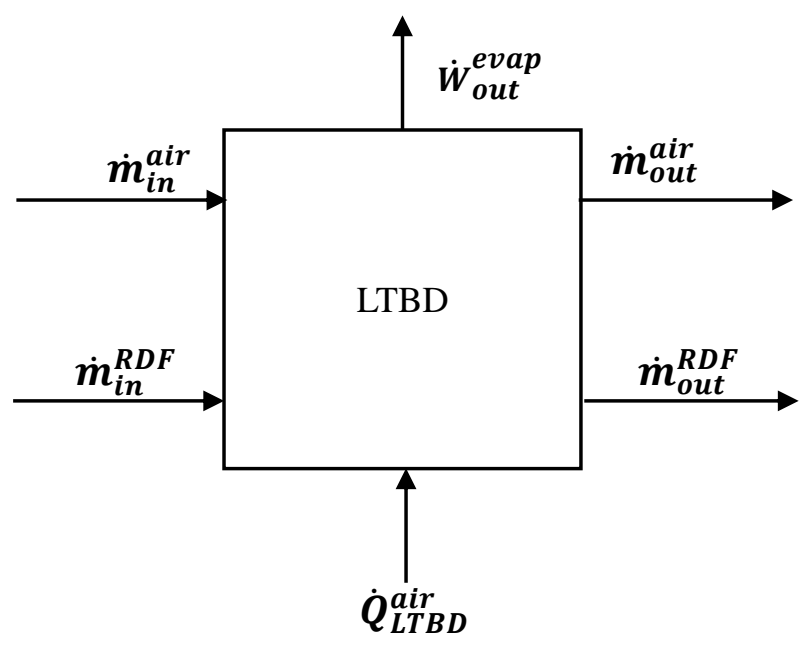

Figure 3. Diagram of energy balance of hot air drying in the LTBD in Souselas

The operational condition set at the dryer for air flow $\left(\dot{m}_{i n}^{\text {air }}\right)$ is $119400 \mathrm{Nm}^{3} / \mathrm{h}$. Knowing the air density is $1.29 \mathrm{~kg} / \mathrm{Nm}^{3}$, the air mass flowrate $\dot{m}_{i n}^{\text {air }}$ is $154294 \mathrm{~kg} / \mathrm{h}$.

The quantity of evaporated water $(\dot{W})$ during the performance test can be determined by equation (1):

$$
\dot{W}_{\text {out }}^{\text {evap }}=\dot{m}_{\text {in }}^{R D F}\left(1-\frac{100-w_{\text {in }}}{100-w_{\text {out }}}\right)
$$

Where,

- $\dot{m}_{i n}^{R D F}=7.5 t / h$;

- $w_{\text {in }}=38.3 \%$; 
- $w_{\text {out }}=8.2 \%$.

Therefore, the drying process evaporates 2.46 tonnes of water per hour from the flow of RDF.

The minimum energy required to evaporate water at a room temperature of $15^{\circ} \mathrm{C}$ is given by the enthalpy of evaporation of saturated water $\left(\mathrm{h}_{\mathrm{fg}}\right)$ (Çengel \& Boles, 2002), which is 2465.9 $\mathrm{kJ} / \mathrm{kg}$. To evaporate 2.46 tonnes of water per hour, as previously determined, a minimum quantity of energy ( $\left.\dot{Q}_{\text {evaporation }}\right)$ of $1684 \mathrm{~kW}$ is required.

It is possible to calculate the amount of heat transferred from the waste hot air flow from the clinker cooler in the LTBD, using equation (2)

$$
\dot{Q}_{L T B D}^{a i r}=\dot{m} \overline{C p} \Delta T
$$

Where,

$\dot{Q}_{L T B D}^{\text {air }}$ - air energy flowrate $(\mathrm{kJ} / \mathrm{h})$;

$\dot{m}$ - air mass flowrate $(\mathrm{kg} / \mathrm{h})$;

$\overline{C p}$ - average specific heat capacity of the air $(\mathrm{kJ} / \mathrm{kgK})$;

$\Delta T$ - temperature difference $(\mathrm{K})$.

According to the table of thermophysical properties of gases at atmospheric pressure (Incropera, 1996), the specific heat for both air temperatures at the inlet and the outlet of the dryer are $1.007 \mathrm{~kJ} / \mathrm{kgK}$ at $300 \mathrm{~K}$ and $1.009 \mathrm{~kJ} / \mathrm{kgK}$ at $350 \mathrm{~K}$. Using the average of these specific heat values, one can determine that $\dot{Q}_{L T B D}^{a i r}$ is $2048 \mathrm{~kW}$.

This represents the real heat flowrate, because it was calculated with measured data from the installed dryer in Souselas, thus taking into account the minimum energy required to evaporate the water from the RDF, as well as other process inefficiencies of the dryer. When compared to the theoretical minimum required energy to evaporate 2.46 tonnes of water per hour, $\dot{Q}_{\text {evaporation }}$, one can conclude that the dryer has an efficiency of $82 \%$.

If instead of using the waste heat from the clinker cooler in the LTBT, the Souselas plant resorted to hot water as a heat source, a heat exchanger would be installed in the dryer and a boiler would have to be installed along with it, as represented in Figure 4. 


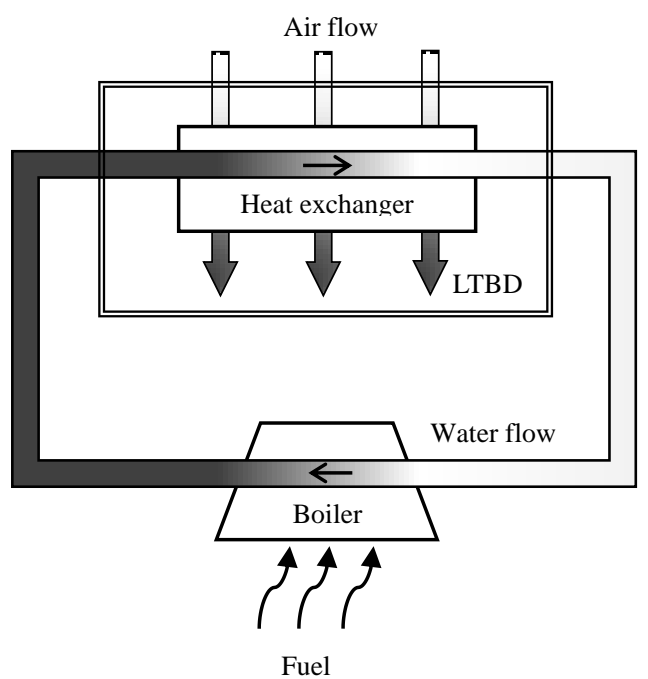

Figure 4. Diagram of energy flows in the LTBD in Souselas with hot water as heat source

An energy balance was developed in order to determine the amount of fuel that was necessary to produce the required energy to dry the RDF in the LTBD until its moisture content was $8.2 \%$ with hot water as a heat source.

As suggested by the LTBD technology supplier, if the dryer were to resort to a hot water system instead of waste heat, the water flow would be required to have a flow temperature of $90^{\circ} \mathrm{C}$ and a return flow temperature of $70^{\circ} \mathrm{C}$.

Knowing the enthalpies of saturated liquid water (Çengel \& Boles, 2002) at those temperatures $\left(376.92 \mathrm{~kJ} / \mathrm{kg}\right.$ at $90^{\circ} \mathrm{C}$ and $292.98 \mathrm{~kJ} / \mathrm{kg}$ at $70^{\circ} \mathrm{C}$ ), it is possible to determine, through equation 3 , that a water flow ( $\dot{m}_{\text {water }}$ ) of $88 \mathrm{~m}^{3} / \mathrm{h}$ was required.

$$
\dot{Q}_{L T B D}^{\text {water }}=\dot{m}_{\text {water }} \times\left(h_{f_{T=90^{\circ} \mathrm{C}}}-h_{f_{T=70^{\circ} \mathrm{C}}}\right)
$$

Considering that both systems would require the same amount of energy, that is, $\dot{Q}_{L T B D}^{\text {air }}=$ $\dot{Q}_{L T B D}^{w a t e r}=2048 \mathrm{~kW}$, and assuming a range efficiency of $80-90 \%$ for the boiler, one can determine the required fuel energy, given by equation 4 ,

$$
\dot{Q}_{\text {fuel }}^{\text {water }}=\frac{\dot{Q}_{L T B D}^{\text {water }}}{\eta_{\text {boiler }}}
$$

which can vary between $8191 \mathrm{MJ} / \mathrm{h}$ (for a 90\% efficiency) and $9215 \mathrm{MJ} / \mathrm{h}$ (for an $80 \%$ efficiency).

\section{Results and Discussion}

\subsection{Energy Balance}

It is possible to quantify the impacts of using natural gas to produce hot water for the LTBD, as represented in Figure 5. Knowing the quantity of fuel energy required to produce hot water 
with an energy content of $2048 \mathrm{~kW}$ and the lower heating value (LHV) for natural gas (48 $\mathrm{MJ} / \mathrm{kg}$ ), according to the Intergovernmental Panel on Climate Change (2006), it is possible to determine the necessary quantity of natural gas, which can vary between 23 and $26 \mathrm{~kg}$ of fuel per tonne of wet RDF, depending on the boiler efficiency.

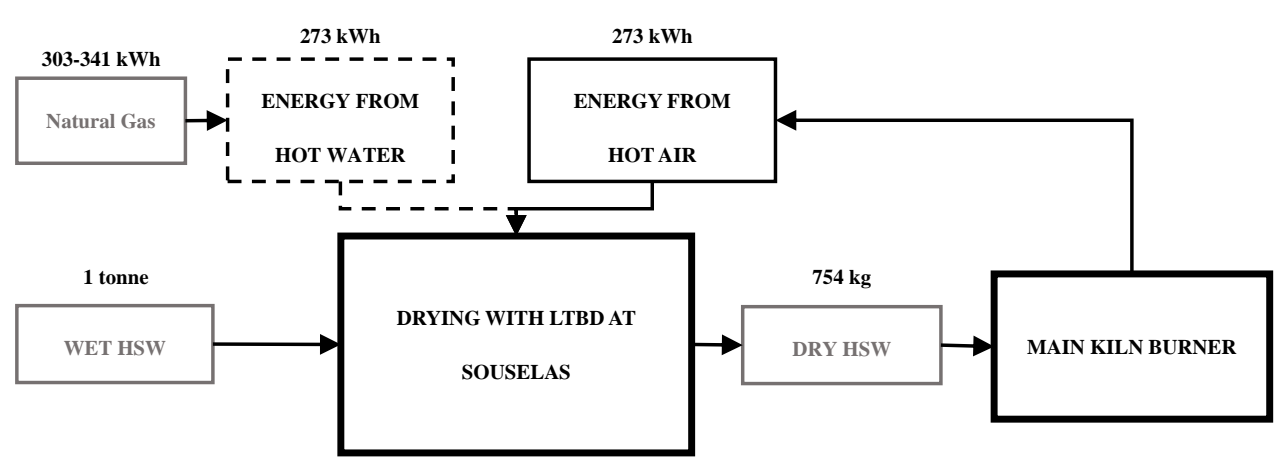

Figure 5. Schematics of the drying process at Souselas LTBD with two different heat sources

With the results of the energy balance of the LTBD it is possible to develop an environmental assessment based on LCA-based environmental indicators. The method ILCD 2011 Midpoint v1.09 (European Commission et al., 2010), which is currently recommended at a European level, was applied in order to calculate the environmental impacts from heat production with natural gas.

The use of the ILCD method in LCA software SimaPro (PRé Consultants, 2018) provides a set of indicators for different impact categories that reflect potential impacts related to pollutant emissions or resource consumption thus allowing to determine the environmental impacts of heat production with natural gas at the characterisation stage (with physical units), as depicted in Table 4, and at the normalisation stage (results are normalised by the impact of an average citizen's activity). From these results, it is then possible to identify the more relevant environmental impact categories (Figure 6).

Table 4. Classification and characterisation of the impacts of heat production from natural gas for the functional unit (Method: ILCD 2011 Midpoint+ V1.09 / EC-JRC Global, equal weighting)

\begin{tabular}{|l|l|l|l|}
\hline \multicolumn{1}{|c|}{ Classification } & \multicolumn{3}{c|}{ Characterisation } \\
\hline Impact Category & $80 \%$ boiler efficiency & $\begin{array}{c}90 \% \text { boiler } \\
\text { efficiency }\end{array}$ & \multicolumn{1}{c|}{ Unit } \\
\hline Climate change & 83.8895 & 74.5685 & $\mathrm{~kg} \mathrm{CO}_{2}$ eq \\
\hline Ozone depletion & 0.0000 & 0.0000 & $\mathrm{~kg} \mathrm{CFC}-11$ eq $^{-1}$ \\
\hline Human toxicity, non-cancer effects & 0.0000 & 0.0000 & $\mathrm{CTUh}$ \\
\hline Human toxicity, cancer effects & 0.0000 & 0.0000 & $\mathrm{CTUh}$ \\
\hline Particulate matter & 0.0095 & 0.0084 & $\mathrm{~kg} \mathrm{PM2.5} \mathrm{eq}$ \\
\hline Ionizing radiation HH & 1.5752 & 1.4002 & $\mathrm{kBq} \mathrm{U}_{235}$ eq \\
\hline Ionizing radiation E (interim) & 0.0000 & 0.0000 & $\mathrm{CTUe}$ \\
\hline Photochemical ozone formation & 0.0712 & 0.0633 & $\mathrm{~kg} \mathrm{NMVOC} \mathrm{eq}$ \\
\hline Acidification & 0.1157 & 0.1028 & molc H+ eq \\
\hline
\end{tabular}




\section{Macrothink}

Environmental Management and Sustainable Development

ISSN 2164-7682

2019, Vol. 8, No. 2

\begin{tabular}{|l|l|l|l|}
\hline Terrestrial eutrophication & 0.1695 & 0.1506 & molc N eq \\
\hline Freshwater eutrophication & 0.0006 & 0.0005 & $\mathrm{~kg} \mathrm{P} \mathrm{eq}$ \\
\hline Marine eutrophication & 0.0155 & 0.0137 & $\mathrm{~kg} \mathrm{~N}$ eq \\
\hline Freshwater ecotoxicity & 5.0158 & 4.4584 & $\mathrm{CTU}$ \\
\hline Land use & 46.9055 & 41.6938 & $\mathrm{~kg} \mathrm{C}$ deficit \\
\hline Water resource depletion & -0.0001 & 0.0000 & $\mathrm{~m}^{3}$ water eq \\
\hline Mineral, fossil \& renewable resource depletion & 0.0001 & 0.0001 & $\mathrm{~kg} \mathrm{Sb} \mathrm{eq}$ \\
\hline
\end{tabular}

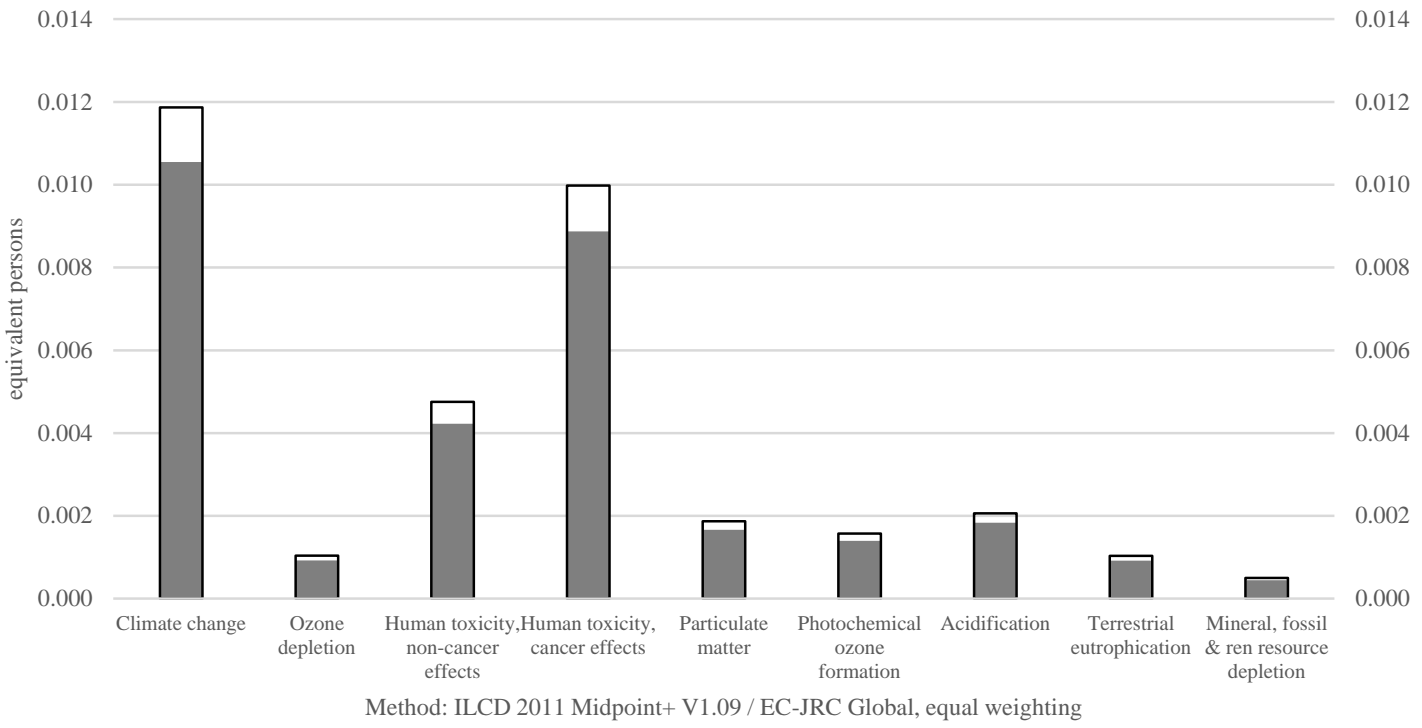

- $90 \%$ efficiency $\square 80 \%$ efficiency

Figure 6. Avoided impacts of heat production from natural gas for drying one tonne of wet RDF with a boiler efficiency of 80\% and 90\% (Method: ILCD 2011 Midpoint+ V1.09 / EC-JRC Global, equal weighting)

There is clear evidence of the benefits of using waste heat as a heat source for the LTBD in comparison to hot water with heat production with natural gas. These benefits are more significant in the climate change category, mostly due to the emission of methane in its combustion, which has a high global warming potential value. The combustion of natural gas obviously results in significant impacts on fossil depletion.

\subsection{Dryer Implementation Results}

Operational results of co-processing dried solid hazardous waste mixtures during one year of operation of the dryer are depicted in Table 5.

Table 5. Operational results of the dryer's first year of operation in Souselas cement plant

\begin{tabular}{|c|c|c|c|}
\hline & & Inlet (40\% moisture) & Outlet (15\% moisture) \\
\hline \multirow[t]{3}{*}{ Alternative fuel } & Type & \multicolumn{2}{|c|}{ HWM } \\
\hline & Consumed amount (t) & 13096 & 8755 \\
\hline & LHV $(\mathrm{kcal} / \mathrm{kg})$ & 2900 & 4338 \\
\hline \multicolumn{2}{|c|}{ Thermal substitution (\%) } & \multicolumn{2}{|l|}{$4.5 \%$} \\
\hline \multirow[t]{3}{*}{ Replaced fuel } & Type & \multicolumn{2}{|l|}{ Petcoke } \\
\hline & LHV (kcal/kg) & \multicolumn{2}{|l|}{7609} \\
\hline & Saved amount (t) & \multicolumn{2}{|l|}{4991} \\
\hline
\end{tabular}


With the project implementation it was possible to increase the RDF feed to the kiln main burner from the previous $2.5 \mathrm{tph}(30-40 \%$ average moisture) to a maximum of 7 tph $(15 \%$ moisture) corresponding to $30-50 \%$ of RDF total thermal substitution (main burner + precalciner). The limitation of this process is the chlorine content in RDF and, as such, the dryer has more capacity than what can be used in the kiln system.

As a result of the implementation of the drying technology, solid hazardous waste mixtures can now fulfil the requirements for co-processing and be safely disposed of, whereas if not for this activity, this waste stream would be landfilled and petcoke would have been used instead. Co-processing of this waste stream therefore avoided the emission of four thousand tonnes of $\mathrm{CO}_{2}$.

\section{Conclusions}

This paper determined the potential environmental benefits of the low temperature belt dryer installed at Souselas cement plant that reuses excess hot air from clinker production to dry $\mathrm{RDF}$ for co-processing in the main kiln burner.

A technical assessment was developed describing the success of the installation due to its fully-automated process with negligible maintenance requirements during its first year of operation and its capability to dry a wide variety of RDF while ensuring the compliance of all EU environmental requirements. The installation of the dryer helped to reduce the Souselas plant's dependency on fossil fuels and decrease its $\mathrm{CO}_{2}$ emissions by increasing the use of alternative fuels in its fuel mix.

Dryers can be powered by all different types of fuels, such as natural gas or biomass, however, by using excess hot air, the LTBD in Souselas further reduces fuel consumption as well as its production costs. If the available waste heat was not the energy source for the dryer then a system of hot water production that includes a boiler and a heat exchanger would need to be installed in order to produce drying hot air. The carried out streamlined LCA determined that the dryer would have required between 1092 and $1229 \mathrm{MJ}$ of fuel per tonne of wet RDF, depending on the boiler efficiency. If natural gas were to be used, it would have resulted in $\mathrm{CO}_{2}$-eq emissions between 75 and $84 \mathrm{~kg}$ per tonne of wet RDF to be dried.

The dryer is a proof-of-concept project that can easily be extended to other facilities, not only cement plants but also waste incinerators or other energy intensive industries. The replication of this project at most cement kilns and other waste-to-energy solutions would potentially boost the environmental benefits of the process at a national level by diverting substantial quantities of waste from landfill which couldn't have been recovered before, thus addressing the limitation of low quality of national RDF due to high moisture content in the national waste management sector.

\section{Acknowledgement}

The authors gratefully acknowledge the financial support of the funded project by the European Regional development Fund (ERDF), granted in the Operational Programme for Competitiveness and Internationalisation - COMPETE 2020, under project 
POCI-01-0249-FEDER-000770.

\section{References}

Alamia, A., Ström, H., \& Thunman, H. (2015). Design of an integrated dryer and conveyor belt for woody biofuels. Biomass and Bioenergy, 77, 92-109.

http://dx.doi.org/10.1016/j.biombioe.2015.03.022

Amiri, R. E., \& Mohammadi, S. (2018). Energetic and exergetic optimized Rankine cycle for waste heat recovery in a cement factory. Applied Thermal Engineering, 132, 410-422. https://doi.org/10.1016/j.applthermaleng.2017.12.076

Aranda, U. A., López-Sabirón, A. M., Ferreira, G., \& Llera, S. E. (2013). Uses of alternative fuels and raw materials in the cement industry as sustainable waste management options. Renewable and Sustainable Energy Reviews, 23, 242-260.

http://dx.doi.org/10.1016/j.rser.2013.02.024

Asadi, F. (2016). Drying of Refuse-Derived Fuel (RDF) (Master's Thesis). Faculty of Technology of the University College of Southeast Norway. Kongsberg, Norway.

Baidya, R., Ghosh, S. K., \& Parlikar, U. V. (2017). Sustainability of cement kiln co-processing of wastes in India: a pilot study. Environmental Technology, 38(13-14), 1650-1659. http://dx.doi.org/10.1080/09593330.2017.1293738

Berardi, P., Almeida, M., \& Dias, J. (2016). Municipal Solid Waste - Study of Refuse Derived Fuel viability in Portugal with focus on regional planning. Venice2016, Sixth International Symposium on Energy from Biomass and Waste, Venice, Italy.

Çengel, Y., \& Boles, M. (2002). Thermodynamics: An Engineering Approach. $4^{\text {th }}$ edition, McGraw-Hill.

Ecofys (2017). Status and prospects of co-processing of waste in EU cement plants - Case Studies. [Online] Available:

https://cembureau.eu/news-views/publications/status-and-prospects-of-co-processing-of-wast e-in-eu-cement-plants/ (February 28, 2019).

European Commission (2000). Commission Decision of 3 May 2000 replacing Decision 94/3/EC establishing a list of wastes pursuant to Article 1(a) of Council Directive 75/442/EEC on waste and Council Decision 94/904/EC establishing a list of hazardous waste pursuant to Article 1(4) of Council Directive 91/689/EEC on hazardous waste (2000/532/EC).

European Commission (2011a). Communication from the Commission to the European Parliament, the Council, the European Economic and Social Committee and the Committee of the regions. A resource-efficient Europe - Flagship initiative under the Europe 2020 strategy. Brussels: European Commission (COM(2011)21).

European Commission (2011b). Resource-efficient Europe MEMO/11/43. Brussels: European Commission.

European Commission (2012). Guidance on the interpretation of key provisions of Directive 
2008/98/EC on waste. Brussels: Directorate-General Environment.

European Commission (2017). Communication from the Commission to the European Parliament, the Council, the European Economic and Social Committee and the Committee of the Regions. The role of waste-to-energy in the circular economy. Brussels: European Commission (COM(2017) 34 final).

European Commission, Joint Research Centre and Institute for Environment and Sustainability (2010). International Reference Life Cycle Data System (ILCD) Handbook General guide for Life Cycle Assessment - Detailed guidance. First edition March 2010. EUR 24708 EN. Luxembourg. Publications Office of the European Union.

Genon, G., \& Brizio, E. (2008). Perspectives and limits for cement kilns as a destination for RDF. Waste Management, 28(11), 2375-2385.

http://dx.doi.org/10.1016/j.wasman.2007.10.022

Georgiopoulou, M., \& Lyberatos, G. (2018). Life cycle assessment of the use of alternative fuels in cement kilns: A case study. Journal of Environmental Management, 216, 224-234. http://dx.doi.org/10.1016/j.jenvman.2017.07.017

Global Cement and Concrete Association (2018). GCCA Sustainability Guidelines for co-processing fuels and raw materials in cement manufacturing. [Online] Available: https://gccassociation.org/sites/default/files/data/files/gcca_guidelines_fuelsrawmaterials_v0. pdf (February 28, 2019).

Incropera, F. (1996). Fundamentals of Heat and Mass Transfer. $4^{\text {th }}$ edition, John Wiley \& Sons.

Intergovernmental Panel on Climate Change (2006). 2006 IPCC Guidelines for National Greenhouse Gas Inventories. Eggleston, H. S., Buendia, L., Miwa, K., Ngara, T., and Tanabe, K. (Eds). Prepared by the National Greenhouse Gas Inventories Programme. Published: IGES, Japan.

Johansen, van D. T. (2010). Modelling and Model Predictive Control of a Conveyor-Bel Dryer Applied to the Drying of Fish Feed (Master's thesis). Norwegian University of Science and Technology. Trondheim, Norway.

Joint Research Council (2013). Best Available Techniques (BAT) Reference Document for the Production of Cement, Lime and Magnesium Oxide. Luxembourg: Publications Office of the European Union. http://dx.doi.org/10.2788/12850

Karellas, S., Leontaritis, A.-D., Panousis, G., Bellos, E., \& Kakaras, E. (2013). Energetic and exergetic analysis of waste heat recovery systems in the cement industry. Energy, 58, 147-156. https://doi.org/10.1016/j.energy.2013.03.097

Khurana, S., Banerjee, R., \& Gaitonde, U. (2002). Energy balance and cogeneration for a cement plant. Applied Thermal Engineering, 22(5), 485-494.

https://doi.org/10.1016/s1359-4311(01)00128-4 
Mäkelä, M., Edler, J., \& Geladi, P. (2017). Low-temperature drying of industrial biosludge with simulated secondary heat. Applied Thermal Engineering, 116, 792-798.

http://dx.doi.org/10.1016/j.applthermaleng.2017.02.010

Nzioka, A., Hwang, H., Kim, M., Troshin, A., CaoZheng, Y., \& Kim, Y. (2016). Experimental Investigation of drying process for Mixed Municipal Solid Waste: Case Study of Wastes Generated in Nairobi, Kenya. International Journal of Advances in Agricultural and Environmental Engineering, 3(1), 87-91. http://dx.doi.org/10.15242/IJAAEE.ER01160039

Ökopol GmbH (2004). Definition of waste recovery and disposal operations. Part A recovery and disposal operations. Report compiled for the Directorate General Environment, Nuclear Safety and Civil Protection of the Commission of the European Communities. Hamburg: Germany [Online] Available:

http://ec.europa.eu/environment/waste/studies/pdf/r_d_part_a.pdf (February 28, 2019).

PRé Consultants (2018). SimaPro 8.0.5. PRé Consultants, Amersfoort, the Netherlands.

Rahman, A., Rasul, M. G., Khan, M. M. K., \& Sharma, S. (2013). Impact of Alternative Fuels on the Cement Manufacturing Plant Performance: An Overview. Procedia Engineering, 56, 393-400. http://dx.doi.org/10.1016/j.proeng.2013.03.138

Reza, B., Soltani, A., Ruparathna, R., Sadiq, R., \& Hewage, K. (2013). Environmental and economic aspects of production and utilization of RDF as alternative fuel in cement plants: A case study of Metro Vancouver Waste Management. Resources, Conservation and Recycling, 81, 105-114. http://dx.doi.org/10.1016/j.resconrec.2013.10.009

Sarc, R., Lorber, K., Pomberger, R., Rogetzer, M., \& Sipple, E. (2014). Design, quality, and quality assurance of solid recovered fuels for the substitution of fossil feedstock in the cement industry. Waste Management \& Research, 32(7), 565-585.

http://dx.doi.org/10.1177/0734242x14536462

Stela (2018). Low-temperature belt dryer for alternative fuels. Stela Drying Technology [Online] Available:

https://www.stela.de/en/app/media/resource/_j59hge06.deliver?\&layout=og.pdf\&mode=dow nload (February 28, 2019).

Supino, S., Malandrino, O., Testa, M., \& Sica, D. (2016). Sustainability in the EU cement industry: the Italian and German experiences. Journal of Cleaner Production, 112, 430-442. http://dx.doi.org/10.1016/j.jclepro.2015.09.022

The European Cement Association (2015). Cement, concrete \& the circular economy. [Online] Available:

https://cembureau.eu/media/1229/9062_cembureau_cementconcretecirculareconomy_coproc essing_2016-09-01-04.pdf (February 28, 2019).

United Nations Environment Programme (2011a). Basel Convention Technical guidelines on the environmentally sound co-processing of hazardous wastes in cement kilns. Geneva: United Nations 


\section{Macrothink}

Environmental Management and Sustainable Development

ISSN 2164-7682 2019, Vol. 8, No. 2

United Nations Environment Programme (2011b). Basel Convention Revised Technical Guidelines for the Environmentally Sound Management of Used and Waste Pneumatic Tyres. Geneva: United Nations.

Wang, J., Dai, Y., \& Gao, L. (2009). Exergy analyses and parametric optimizations for different cogeneration power plants in cement industry. Applied Energy, 86(6), 941-948. https://doi.org/10.1016/j.apenergy.2008.09.001

Wernet, G., Bauer, C., Steubing, B., Reinhard, J., Moreno-Ruiz, E., \& Weidema, B. P. (2016). The ecoinvent database version 3 (part I): overview and methodology. International Journal of Life Cycle Assessment, 21(9), 1218-1230. https://doi.org/10.1007/s11367-016-1087-8

\section{Copyright Disclaimer}

Copyright for this article is retained by the author(s), with first publication rights granted to the journal.

This is an open-access article distributed under the terms and conditions of the Creative Commons Attribution license (http://creativecommons.org/licenses/by/3.0/). 